INDIAN SALTPETRE. ${ }^{1}$

THE brochure before us, issued by the Agricultural Research Institute, Pusa, is the work of the Imperial Agricultural Bacteriologist, and is an interesting and valuable account of an

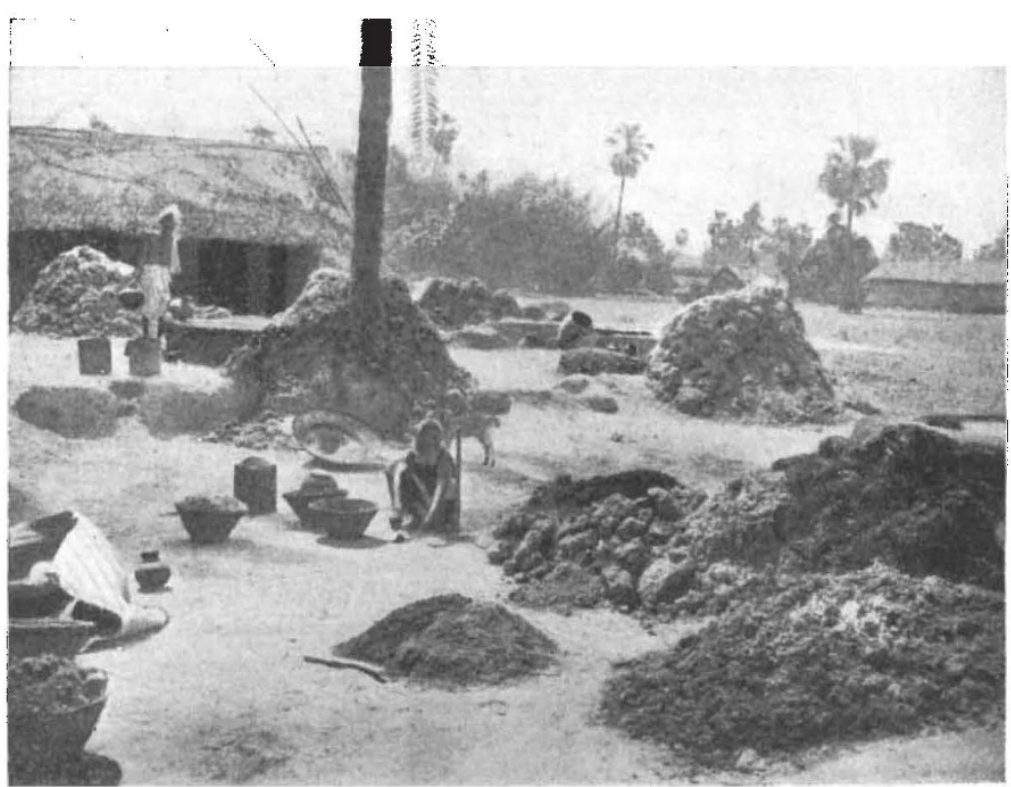

operator is termed, for extracting saltpetre from the surface layer, or calcareous portions, of the alluvium have been frequently, although not always accurately, described. Mr. Hutchinson has studied these methods in detail, and his observations throw considerable light upon a procedure which shows little variation throughout India and is based upon the accumulated experience of generations of predecessors.

The supply of saltpetre is almost entirely obtained from the soil in the immediate neighbourhood of human habitations, or of abandoned village sites where nitrogenous organic refuse, consisting largely of excrementitious matters of men and animals, has accumulated.

The surface-soil, or chhilua, scraped to the depth of a quarter of an inch, is mixed with an equal quantity of residual earth from previous extractions, known as bhinjua, and is placed by treading into a circular filter-bed, or kuthia, consisting of a mud wall and floor plastered with clay, and having a bottom layer of bamboos important village industry, which, as is well known, has long been carried on in various districts of India where the factors determining the formation of potassium nitrate, as a soil conand straw. Water is poured over the earth and, percolating through the loosely compacted soil, is collected in an earthen vessel. The first runnings, or murhan, contain most of the nitrate, mixed, of stituent, are sufficiently favourable. These factors, as summarised by the author, are :-

(I) Nitrifiable organic matter in suitable proportion in the soil.

(2) Lime.

(3) Water, not only in sufficient amount for nitrification, but also distributed in the soil in such a way as not to interfere with aeration, and to provide for continual capillary rise to the surface.

(4) Soil of such a texture as to allow of continuous upward movement of water from the subsoil to the surface.

(5) Climate ensuring a provision of adequate moisture and temperature during part of the year and complete, or nearly complete, absence of rainfall, coupled with low humidity during a sufficiently long period to ensure the capillary rise of subsoil water consequent on rapid surface evaporation.

The methods employed by the nuniah, as the 1 "Saltpetre: Its Origin and Extraction in India." By C. M. Hutchinson.
Bulletin No. 68 of the Agricultural Research Institute, Pusa. (Calcutta: Government Printing Office, I9ז7.)

NO. 2492, VOL. 99]

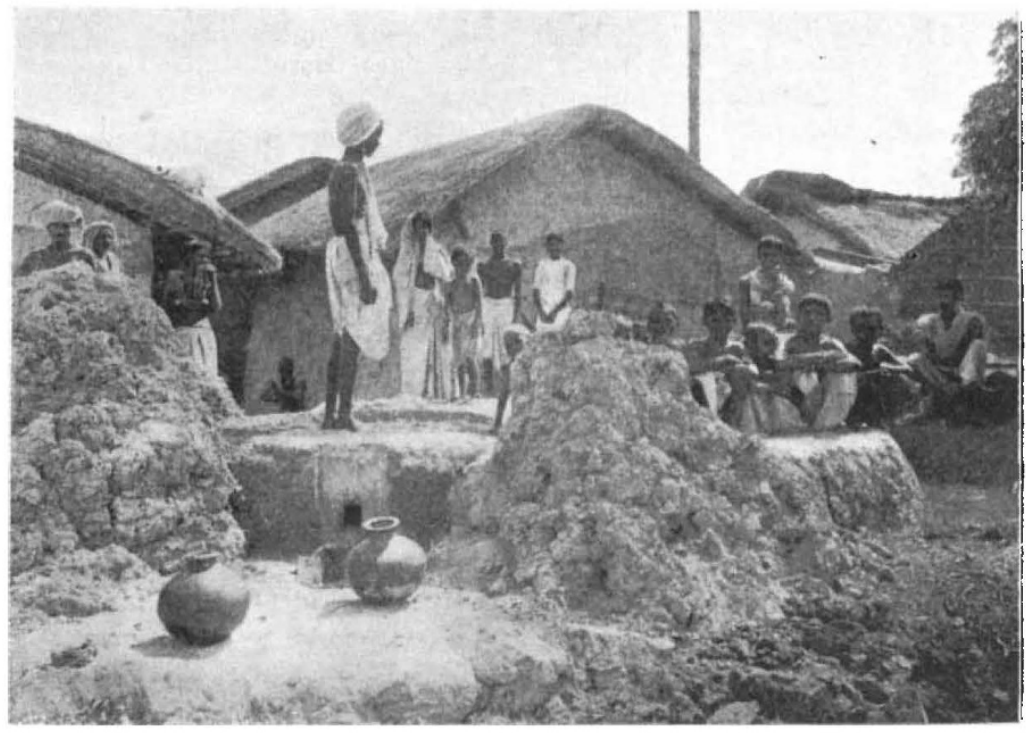

FIG. 2.-Treading the earth into the kuthin for extraction. From Bulletin No. 68, Agricultural Research Institute, Pusa.

course, with a greater or less quantity of common salt. The solution is concentrated to the crystallising point by boiling in an open pan over a fire of dead bamboo leaves, the ashes of which, being rich in potash, are added to the extracted earth, or 
bhinjua, to be mixed afterwards with fresh chhilua. The nuniah seldom or never attempts to separate the mixed salts, as this is forbidden to him by the Salt Department. The crude product is sold, usually through a middleman, to the refiner, who works under Government supervision.

The restrictions of the Indian Salt Department, according to Mr. Hutchinson, undoubtedly hamper the operations of the nuniah, who has no inducement to improve his methods so as to turn out a better article. The whole process as at present carried on is essentially wasteful and uneconomical, and might be greatly improved in the absence of official interference. The conditions for the most economical production of saltpetre are well understood by the nuniah, and it is to be regretted that he should not be encouraged to make full use of his knowledge and experience.

The Bulletin is an important contribution to an interesting process of manufacture based primarily upon bacteriological agencies. It forms an excellent example of a purely empirical method which has been elaborated by the accumulated experience of centuries, but the rationale of which has only been made clear by modern biological science. In view of the growing scarcity of nitrates and of their increasing importance in the arts, especially in agriculture, it is to be hoped that the Indian Government will neglect no opportunity of conserving and extending an industry which is peculiarly well adapted to Indian conditions.

T. E. THORPE.

\section{THE PROMOTION OF TECHNICAL} OPTICS.

THE long-delayed steps which-as announced in Nature of May 24 (p. 257) and June 14 (p. $3^{1} 7$ )-have been taken by the Government and the London County Council in concert for establishing the study of optics and of the manufacture of optical appliances upon a proper footing in this country, have given great satisfaction to all who are in a position to appreciate the importance of that measure. That the turning of this new leaf should be among the earliest consequences of the war is a fact both of intrinsic importance and of good augury. The importance of properly organised manufactures of optical glass and of optical instruments has been manifest, and has been pressed upon the Government with great weight of expert authority by the British Science Guild and other bodies for many years past. But in the days before the war, when the optimist was accounted the best as well as the pleasantest of counsellors, it was impossible to secure the attention of our rulers for so modest a proposal as the establishment upon an adequate scale of a school of practical optics.

It is with something more than a sigh of relief that we find ourselves after three years of war able to record this sound decision of the British Government. For, indeed, the matter for congratulation is that there is a British Government still in a position to act. The thought of what range-finders mean to the British Navy, and of how narrowly we escaped being dependent upon the enemy for our supply of these essential instruments, is almost enough to make one shudder even under the wing of a Royal Navy that has swept the sea. It chanced by the happiest of happy accidents that the range-finder which finds the range for our own and all the other navies was of British invention, also that the inventor took the trouble to establish its manufacture in this country as a private enterprise, and, by consequence, that when the war commenced we were in the best possible position to provide both Army and Navy with these important instruments. The Army can, indeed, use alternatives, but the Navy is shut up to the range-finder. Had that been a German monopoly the battle of Jutland might quite conceivably have been the end of British seapower. Considerations such as these lead us to place on record the sense of immense relief with which we note the new attitude of the Government towards one of the things that matter.

The task before the new department is a large one, and it is beset with many difficulties. That task is chiefly educational, but it is by no means only the education of the student of optics that is here in question. Parliament, and the greater public to which Parliament is responsible, stand in need of education also. The facts just now alluded to concerning the supply of range-finders afford one illustration, and a very striking one, of this necessity. A necessity of a totally different kind is exhibited by the conditions governing the supply of optical glass. This, as is perfectly well known, has been for many years past, in large measure, a monopoly of one Jena glass manufacturer. That arrangement was in a certain sense a good and convenient one. The Jena glasses were excellent in quality-no one could reasonably expect to better them. Specialising in this line, the Jena house was able to produce them in great variety, and did, in fact, list and stock many varieties of optical glass for which the market demand was inconsiderably small.

Competitive manufacture under these conditions could only be wasteful manufacture, and the British glass-makers took what was, from the commercial point of view, the sound position that it was not worth while to spoil a market for a rival which they had no chance of exploiting for their own advantage. Indeed, when it is recognised that the whole world's trade in optical glass would not yield a profit that any successful stockbroker would think considerable, it is easy to understand the reluctance of business men to embark upon a troublesome business with no better prospect than that of largely destroying this modest prosperity and then joining in a scramble for the residue.

How, then, are Parliament and the British nation to be made aware of the technical importance of an industry which is commercially of so small. account? That is one of the problems with which the new department is faced. 